\title{
An Analyzing Of Factors Affecting On Profitability In BRI Syariah
}

\author{
Kiki Sagita ${ }^{1 *}$, Rendra Erdkhadifa $^{l}$ \\ ${ }^{1}$ Islamic Banking Department, UIN Sayyid Ali Rahmatullah, Indonesia
}

\begin{abstract}
The research is motivated by the level of profitability which is a benchmark for Islamic banks in generating profits which is still not stable and tends to decrease every year. The factors that can affect the level of profitability of Islamic banks are Third Party Funds (DPK), Capital Adequacy Ratio (CAR), Non Performing Financing (NPF), Financing to Deposit Ratio (FDR), Net Operating Margin (NOM) and Operating Expenses for Operating Income ( BOPO). The purpose of this study was to determine the effect of the variables TPF, CAR, NPF, FDR, NOM and BOPO on the profitability of BRI Syariah Bank and to find out which variables had the most significant effect on the profitability of BRI Syariah Bank. The data used in this study is secondary data obtained from the quarterly financial statements of BRI Syariah Bank for the period 2012 to 2020. The data analysis technique used multiple linear regression consisting of multicollinearity test, multiple regression analysis, simultaneous test, partial test, and classical assumption test of residuals. The test results show that NPF, CAR, NPF, FDR and NOM have a significant effect on the profitability of BRI Syariah Bank.
\end{abstract}

\section{Introduction}

Economic growth in a country can be characterized by the growth of the banking industry in that country. The more developed the banking industry, the better the economic development of the country itself (Hasibuam 2009). The development of the banking industry will increase the income received by the state. Therefore, every bank is required to provide the best service in order to increase annual profits. The Bank prioritizes service in running its business. In the economy in Indonesia, banks have to compete very tightly to be able to survive. The number of new banks that have emerged has made people more flexible in making their choices. (Santoso, 2000)

Banking is a financial institution that functions as an intermediary between parties who have excess funds and those who lack funds, namely from customers who collect funds and then distribute them to customers who need funds. Banks are the heart and veins of a country's trade and economic development. The more funds a bank has, the greater the opportunity to carry out its activities in achieving its goals. As well as providing other banking services to gain profit and social interests to improve people's living standards. (Dendawijaya, 2009)

* Corresponding author: rendra.erdkhadifa@gmail.com 
The amount of profit obtained by the bank depends on how the bank manages its financial performance.

Financial performance in banking is very important where the bank is a trusted business. If a bank has good financial performance, there will be more people who transact at the bank. Financial performance is also used to determine the extent to which banking developments have been achieved in any given period. (Kasmir, 2007) The achievement of good financial performance and the ability to sustain banking life in the long term depends on many individual and collective decisions that are continuously made by management. Every decision taken will have a financial impact that causes the banking performance to improve or worsen. The bank's financial performance can be assessed from the ratios in the financial statements, one of which is the profitability ratio.(Munawir, 2002)

Profitability is the ability of a bank to generate profits, both from operational activities and from non-operational activities. This ratio measures the effectiveness of the overall management as indicated by the size of the profit earned in relation to sales and investment. The better the profitability ratio, the better the ability to describe the company's high profitability. (Fahmi, 2015) Profitability is used to measure or calculate the profits obtained by banks in a certain period, assessing the position and development of profits from time to time and assessing the amount of net profit after tax and with own capital. To measure the productivity of all funds owned by banks which can also use profitability.

Profitability has an important meaning for the banking world, because the fundamental business objective of banking is to obtain optimal profits by providing financial services to its customers. In addition, investors have an interest in getting benefits from the bank through increasing the investment value and dividends provided by the company. The increase in investment value can be realized by increasing the profitability of the bank. Therefore, profitability performance is an important indicator and can be used by banks in order to show their performance. (Akbar, 2019)

Profitability ratios are divided into several types, one of which is related to assets known as Return On Assets (ROA). ROA is the rate of return or profit generated from asset management and company investment. This ratio is used as an indicator of banking profitability by comparing net income with the total assets of the company. ROA can provide adequate measurement of the overall effectiveness of the company because ROA takes into account the use of assets and profitability in sales. (Kasmir, 2016)

In 2018 and 2019 the level of profitability of Islamic banking in Indonesia also increased by $1.28 \%$ and $1.73 \%$, respectively, this indicates that Islamic banks have good financial performance and there are many people who transact at Islamic banks. However, in 2020 the development of Islamic banking profitability decreased to $1.40 \%$, this decrease occurred due to the ineffectiveness of management in managing its assets due to the Covid 19 Virus pandemic, the decline in profitability could also lead to a decrease in public confidence in Islamic banks. The problem for the banking industry in Indonesia is that it is unable to maintain its profitability so that it remains stable and does not always experience a decline.

Based on the level of profitability, Indonesia has the three best state-owned Islamic banks, namely BRI Syariah Bank, BNI Syariah Bank and Mandiri Syariah Bank. Bank BRI Syariah was established on December 19, 2007, Bank BNI Syariah was established on April 29, 2000 and Bank Syariah Mandiri was established on October 25, 1999. Bank BRI Syariah is the youngest, but Bank BRI Syariah has rapid asset growth and total financing and obtain substantial third-party funding. This confirms the existence of BRI Syariah Bank in Indonesia. Based on its profitability, Bank BRI Syariah has a smaller value when compared to Bank BNI Syariah and Bank Syariah Mandiri.

The following is a picture of the development of BRI Syariah Bank's profitability from 2012 to 2020 : 


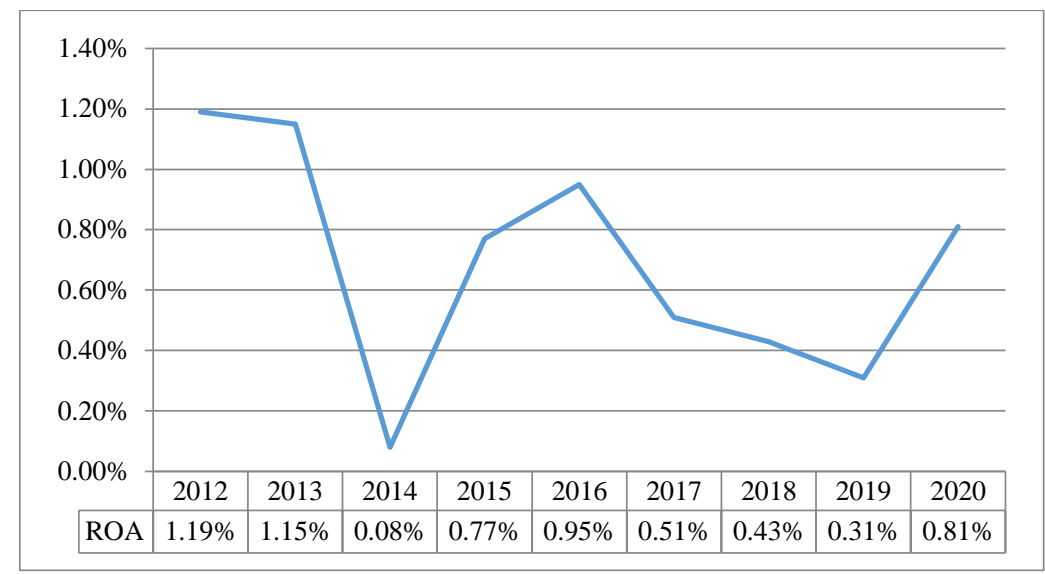

Fig 1. Profitability in BRI Syariah

In Figure 1 the ROA ratio of BRI Syariah Bank in 2012 was 1.19\%, based on Bank Indonesia regulations regarding the soundness of banks, the financial performance of BRI Syariah Banks can be said to be quite healthy. In 2013 1.15\% was said to be quite healthy even though it decreased from the previous year and in 2014 it decreased again to $0.08 \%$ and this ROA ratio could be said to be less healthy. This decline was triggered by the high nonperforming financing that existed at the institution itself and was not matched by the repayment of third party loans that were successfully collected by the bank.

In 2015 and 2016 Bank BRI Syariah began to rise from the decline in ROA that occurred in the previous year, indicating that Bank BRI Syariah was able to overcome the problems faced, the increase in ROA ratio was quite large, namely $0.69 \%$ and $0.18 \%$. Although the size of the increase is said to be good, it is still below the healthy criteria set by Bank Indonesia. However, this increase did not last long, in 2017 to 2019 the decline in ROA occurred again, namely in 2017 the ROA ratio became $0.51 \%$, in 2018 it became $0.43 \%$ and in 2019 it became 0.31\%. In 2018 and 2019 Bank BRI Syariah can be said to be less healthy. The decrease in this ratio was due to the high operational costs at Bank BRI Syariah. In 2020 the ROA ratio of BRI Syariah Bank began to increase again to $0.81 \%$, this shows that BRI Syariah Bank has been able to control its operational costs.

Based on the description of the background of the problem above, it is interesting to raise the issue and examine the variables that can affect banking profitability with the title "An Analyzing Of Factors Affecting On Profitability In BRI Syariah"

\section{Theories}

\subsection{Third Party Fund}

Third party funds are funds collected from the public, both individuals, groups and legal entities in the form of wadiah demand deposits, mudharabah savings, and mudharabah deposits (Muhammad, 2017). Third Party Funds are funds originating from public deposits. Banks can use third party funds to be placed in various posts that can provide opinions, including in the form of credit. (Dendawijaya, 2009) Third party funds (TPF) are funds sourced from the wider community, are an important source for bank operational activities and are a measure of the success of a bank if the bank can bear its operating costs 
from this source of funds. If the third party funds increase, the bank has a greater opportunity and opportunity to obtain higher income.

\subsection{Capital Adequacy Ratio}

CAR or often called the capital ratio is the authorized capital that must be met by the bank. According to Bank Indonesia Regulations, CAR is a ratio that shows how far bank assets that contain risks (credits, investments, securities, claims on other banks) are also financed from the bank's own capital funds in addition to obtaining funds from sources outside the bank. such as public funds, loans (debt), etc. (Defri, 2012). Mudrajad Kuncoro and Suhardjono stated that the greater the Capital Adequacy Ratio (CAR), the greater the bank's profit, the higher the CAR, the better the condition of the bank. In other words, the smaller the risk of a bank, the greater the profit earned by the bank, which means that CAR has a positive effect on ROA, the smaller the CAR, the smaller the ROA obtained by the bank, and vice versa, the greater the CAR, the greater the ROA. obtained by the bank Non Performing Financing

Non-performing financing is financing that has the potential to be unable to repay the financing based on the terms that have been agreed and determined together. Non-performing financing can also be interpreted as financing which in its implementation has not met the desired target, such as: principal returns or profit sharing, current financing and special attention, which has the potential for arrears. (Riyadi, 2006)

\subsection{Financing Deposit to Ratio}

Dendawijaya stated that the Financing to Deposit Ratio (FDR) is the ratio between the total volume of credit or financing disbursed by the bank and the amount of funds received from various sources. With a large distribution of deposits, the bank's income Return on Assets (ROA) will increase, so that FDR has a positive effect on ROA. (Dendawijaya, 2009)

\subsection{Net Operating Margin}

Net Operating Margin is the equation of the Net Income Margin (NIM) ratio because in the Islamic banking system it is not interest-based but based on profit-sharing. So the NOM ratio is the ratio used to measure the ability of productive assets to generate profits. (Umam, 2009). According to Dendawijaya (2009), Net Operating Margin (NOM) is a ratio used to measure the ability of bank management to manage their productive assets to generate net operating income.

\subsection{Operating Costs Operating Income}

Operating Expenses Operational Income (BOPO) is a ratio that shows the amount of comparison between operating expenses or costs to the operating income of a company in a certain period. BOPO has become one of the ratios whose value changes are very concerned, especially for the banking sector, considering that one of the criteria for determining the soundness of banks by Bank Indonesia is the size of this ratio. 


\subsection{Return On Assets}

ROA is a ratio used to measure the ability of bank management to obtain overall profits. The greater the ROA of a bank, the greater the level of profit achieved by the bank and the better the position of the bank in terms of asset use (Dendawijaya, 2009). This ratio describes the success of management in generating overall profit by comparing the profit before tax with total assets. ROA also describes asset turnover as measured by sales volume. The greater the ROA of a bank, the greater the level of profit achieved by the bank and the better the position of the bank from the use of assets.

\subsection{Profitability}

Bank profitability is the ability of a bank to earn a profit expressed as a percentage. Profitability is a ratio to assess the company's ability to seek profit. (Kasmir, 2008) Profitability (profit) is the result of the policies taken by management. Profit ratio to measure how much profit the company can get. The greater the profit level, the better the management in managing the company.

\section{Research Method}

\subsection{Research Type and Approach}

This study uses a quantitative approach. The type of research used is associative research. This research is part of associative research because it shows the influence or relationship between variables

\subsection{Population, Sampling, and Sample}

The population of this study is the entire financial report of BRI Syariah Bank in Indonesia published on the official website. The sampling technique used in this research is non- probability sampling. While the type of non- probability sampling technique used in this study is purposive sampling, where the researcher in this case has certain criteria and considers them based on the research objectives or existing problems. The sample in this study is the financial statements of BRI Syariah Bank in the period 2012-2020 which are presented in quarterly form. In this study, a sample of 36 data was used.

\subsection{Data Sources, Variables, and Measurement Scales}

The type of data used in this research is secondary data. The secondary data referred to in this study is in the form of quarterly financial reports from January 2012 to 2020. This study uses two variables, namely the independent variable and the dependent variable. The independent variables in this study are Third Party Funds (DPK), Capital Adequacy Ratio (CAR), Non Performing Financing (NPF), Financing to Deposit Ratio (FDR), Net Operating Margin (NOM) and Operating Income Operating Expenses (BOPO). While the dependent variable in this study is Profitability. 


\subsection{Data Analysis Method}

\subsubsection{Multicolinearity Test}

The method for testing the existence of this multicollinearity can be seen from the tolerance value or variance inflation factor (VIF). This VIF value is searched through the following formula:

$V I F=\frac{1}{1-R_{j}^{2}}$

\subsubsection{Regression Model}

Linear regression model is a model that describes the relationship between the response variable and the predictor variable. In this research, it is used to find out how much influence TPF, CAR, NPF, FDR, NOM and BOPO have on profitability. The regression equation is:

$\mathrm{Y}=\alpha+\beta_{1} \mathrm{X}_{1}+\beta_{2} \mathrm{X}_{2}+\beta_{3} \mathrm{X}_{3}+\beta_{4} \mathrm{X}_{4}+\beta_{5} \mathrm{X}_{5}+\beta_{6} \mathrm{X}_{6}+e$

\subsubsection{Goodness Of Model}

The method used to measure the goodness of the model in this study is the Coefficient of Determination $\mathrm{R}^{2}$. The value of the coefficient of determination is used to measure how much the variance of the response can be explained by the model. Good model if $\mathrm{R}^{2}$ more than $75 \%$. Here is the equation to find the value

$\mathrm{R}^{2}=1-\frac{S S E}{S S T}=\frac{S S R}{S S T}$

\subsubsection{Partial Test}

The $t$ test is a test used to test whether the independent variable has a significant effect on the dependent variable. Test criteria, namely:The test criteria seen from the t-count and t-table values are as follows:

1) If $t_{\text {test }}>t_{\text {table }}$ rejected $\mathrm{H}_{0}$

2) If $t_{\text {test }}<t_{\text {table }}$ accepted $\mathrm{H}_{0}$

\section{Result and Discussion}

\subsection{Multicolinearity Test}

The following are the results of the multicollinearity test:.

Table 1. Multicolinearity Test Results

\begin{tabular}{|c|c|}
\hline Variable & VIF \\
\hline DPK & 2,933 \\
\hline CAR & 2,459 \\
\hline
\end{tabular}




\begin{tabular}{|c|c|}
\hline NPF & 3,869 \\
\hline FDR & 3,683 \\
\hline NOM & 1,424 \\
\hline BOPO & 1,830 \\
\hline
\end{tabular}

Based on the results of the analysis shown in Table 1 that each variable has a VIF value of less than 10. So it can be stated that the data is free from multicollinearity. Thus it can be said that the variables $\mathrm{X}$ are mutually independent or independent.

\subsection{Multiple Regrssion Analysis}

The following are the results of multiple linear regression analysis:

$$
\begin{aligned}
\mathrm{ROA}= & 8,798-0,003(\mathrm{DPK})-0,008(\mathrm{CAR})-0,045(\mathrm{NPF})-0,005(\mathrm{FDR})+ \\
& 0,061(\mathrm{NOM})-0,078(\mathrm{BOPO})+e
\end{aligned}
$$

Based on the above equation, it can be concluded that the constant value of 8.798 states that if the TPF, CAR, NPF, FDR, NOM and BOPO values are 0, then the ROA value is 8.798. For the regression coefficients from TPF, CAR, NPF, FDR and BOPO, it is stated that each addition of one variable unit will reduce the ROA value by one unit. On the other hand, every one unit decrease in the variable will increase the ROA value by one unit. As for the NOM regression coefficient of 0.061 , it states that for every addition of one NOM unit, it will increase the ROA value of 0.061 one unit.

The results of the coefficient of determination ( ) can be seen in the modal summary table as follows:

Table 2. Multiple Linear Regression Test Results

\begin{tabular}{|c|c|}
\hline Model & $\boldsymbol{R}^{\mathbf{2}}$ \\
\hline Regresi & 0,618 \\
\hline
\end{tabular}

By looking at the size of the values contained in Table 2 of 0.618 or $61.8 \%$, it means that the model is able to explain the actual condition of $61.8 \%$ or the relationship between predictor and response variables is able to explain $61.8 \%$. This also explains that $38.2 \%$ of the profitability variable is influenced by other variables that are not used in the study. The results of the simultaneous test can be seen in the following table:

Table 3. Simultaneous Test Results

\begin{tabular}{|c|c|c|}
\hline F-test & F-table & Sig. \\
\hline 10,421 & 2,43 & 0,000 \\
\hline
\end{tabular}

Based on Table 3, it is known that the F-count value is 10.421 and the F-table value with a significant level $(\alpha)$ of $5 \%$ and a value $F_{(0,05 ; 6 ; 29)}$ of 2.43 , so F-test (10.421) $>$ F-table $(2.43)$ so that the conclusion obtained is rejected H0. This means that there is one $\mathrm{x}$ variable that has a significant effect on the y variable. The rejection decision $\mathrm{H} 0$ can also be seen from the p-value which is less than the significant level value. So that hypothesis 1 is tested, namely 
at least one of the variables that affect the profitability of BRI Syariah Bank. The results of the partial test can be seen in Table 4 below:

Table 4. Partial Test Results

\begin{tabular}{|c|c|c|c|}
\hline Variable & T-test & T-table & Sig. \\
\hline DPK & $-0,402$ & 2,030 & 0,691 \\
\hline CAR & $-0,704$ & 2,030 & 0,487 \\
\hline NPF & $-0,518$ & 2,030 & 0,608 \\
\hline FDR & $-0,717$ & 2,030 & 0,479 \\
\hline NOM & 0,502 & 2,030 & 0,619 \\
\hline BOPO & $-5,377$ & 2,030 & 0,000 \\
\hline
\end{tabular}

Based on Table 4, it can be explained that the partial test results of the DPK, CAR, NPF, FDR and NOM variables are t-count $<\mathrm{t}$-table, it means that the five variables have no effect on profitability. While the significance for the five variables is a significance value $>0.05$, which means that it is not significant. So the conclusion obtained is accept H0, namely TPF, CAR, NPF, FDR and NOM have no significant effect on the Profitability (ROA) of BRI Syariah Bank. The t-count value of BOPO based on Table 4.6 is 5.377 with a negative direction and the t-table value is 2.030 , so t-test $(-5.377)>\mathrm{t}$-table $(2.030)$. While the significance for the BOPO variable is 0.000 when compared to the significance level $(\alpha=$ $0.05)$ so $0.000<0.05$ means significant. So that the conclusions obtained are $\mathrm{H} 0$ rejected and $\mathrm{H} 1$ accepted, this means that the BOPO has a significant negative effect on the Profitability (ROA) of BRI Syariah Bank. So the variable that has a significant effect on the profitability of BRI Syariah Bank is BOPO.

\subsection{Residual Classical Assumption Test}

The following are the results of the Glesjer Test:

Table 5. Glejser Test

\begin{tabular}{|c|c|}
\hline Variable & Sig. \\
\hline DPK & 0,055 \\
\hline CAR & 0,415 \\
\hline NPF & 0,242 \\
\hline FDR & 0,070 \\
\hline NOM & 0,399 \\
\hline BOPO & 0,673 \\
\hline
\end{tabular}

Based on Table 5, it can be seen that the significance value of the six independent variables is more than 0.05 . Thus it can be said that the independent variable has no significant effect on the absolute residual variable or in other words there is no 
heteroscedasticity in the regression model. The following are the results of the independent assumption test using the Durbin-Watson method:

Table 6. Durbin Watson Test

\begin{tabular}{|c|c|}
\hline Model & Durbin-Watson \\
\hline Regresi & 2,194 \\
\hline
\end{tabular}

Based on the results of the autocorrelation test using the Durbin-Watson method, Table 6 shows a value of 2.194. Meanwhile, from the Durbin-Watson table with a significance of 0.05 and the amount of data $(\mathrm{n})=36$, and $\mathrm{k}=6$ ( $\mathrm{k}$ is the number of independent variables) the $\mathrm{dL}$ value is 1.1755 and $\mathrm{dU}$ is 1.7987 . Because the value of DW (2.194) lies between 1.7987 and 2.2013 (4 - 1.7987), the null hypothesis is accepted, which means there is no autocorrelation. The following are the results of the Kolmogorov-Smirnov test:

Table 7. K-S Test

\begin{tabular}{|c|c|}
\hline Variable & $\begin{array}{c}\text { Unstandardized } \\
\text { Residual }\end{array}$ \\
\hline Asymp. Sig. (2-tailed) & 0,194 \\
\hline
\end{tabular}

Based on the results of the One-Sample Kolmogorov-Smirnov Test normality test in Table 7 shows that the Asymp value. Sig ( 2 -tailed) of $0.194>$ the value of the significance level (0.05). The results of the analysis show that the residual data is normally distributed by looking at the sig value which is more than the significance level value.

\section{Conclusion}

Based on the results of the analysis and discussion that have been explained, the conclusion of this study is that from the results of the analysis that has been carried out it can be seen that the magnitude of the influence of TPF, CAR, NPF, FDR, NOM and BOPO on the profitability of BRI Syariah Bank for the period 2012-2020 are as follows: -variables that do not significantly affect the profitability of BRI Syariah Bank are TPF, CAR, NPF, FDR and NOM. While the variable that has a significant negative effect on the profitability of BRI Syariah Bank is BOPO. The variable that has a dominant influence on the profitability of BRI Syariah Bank is the BOPO variable. This is due to the high value of BOPO at BRI Syariah Bank which causes the ROA BRI Syariah banks declined during the study year.

\section{References}

Akbar, Taufiq. 2019. Kajian Kinerja Profitabilitas Bank pada Perspektif Bank Umum Berdasarkan Kegiatan Usaha. Ponorogo: Uwais Inspirasi Indonesia.

Andrianto dan Firmansyah, M. Anang. 2019. Manajemen Bank Syariah (Implementasi Teori dan Praktek). Surabaya: CV. Penerbit Qiara Media.

Arifin, Zainul. 2009. Manajemen Bank Syariah. Tanggerang: Azkia Publisher, 2009.

Ascarya. 2008. Akad \& Produk Bank Syariah. Jakarta: PT. Raja Grafinfo. 
Basuki, Agus Tri. 2019. Bahan Ajar Regresi Berganda. Fakultas Ekonomi dan Bisnis Universitas Muhammadiyah Yogyakarta.

Darmadji, Tjiptono. 1992. Melacak Jejak Kredit Macet. Jakarta: Yayasan Sembada Swakarya.

Defri. 2012. "Pengaruh Capital Adequacy Ratio (CAR), Likuiditas dan Efisiensi Operasional Terhadap Profitabilitas Perusahaan Perbankan yang Terdaftar di BEI". Jurnal manajemen Vol. 01 No. 01.

Fahmi, Irham. 2015. Matematika Keuangan. Bandung:CV Alfabeta.

Fahrudin, Moh. Andrew. "Pengaruh Capital Adquacy Ratio dan Loan To Deposit Ratio Terhadap Return On Asset PT Bank Syariah Mandiri Tbk. periode 2001-2013"

Hariyani, Iswi. 2010. Restrukturisasi dan Penghapusan Kredit Macet. Jakarta: PT Elex Media Komputindo.

Harmono. 2009. Manajemen Keuangan Berbasis Balanced Scorecard Pendekatan Teori, Kasus dan Riset Bisnis. Jakarta: Bumi Aksara.

Hasibuan, Malayu S.P. 2009. Dasar-Dasar Perbankan, (Jakarta: PT Bumi Aksara.

Hery. 2015. Analisis Kinerja Manajemen. Jakarta: Gramindo.

Ismail. 2016. Perbankan Syariah. Jakarta : Prenadamedia Group.

Jatmiko, Dadang Prasetyo. 2017. Pengantar Manajemen Keuangan. Yogyakarta: Diandra Kreatif.

Jumingan. 2006. Analisis Laporan Keuangan, (Jakarta: PT Bumi Aksara, 2006), hal. 239.

Karim, Adiwarman A. 2016. Bank Islam (Analisis Fiqih dan Keuangan). Jakarta: PT. Raja Grafindo Persada.

Kasmir. 2007. Bank \& Lembaga Keuangan Lainnya. Jakarta: PT. Raja Grafindo Persada.

Kasmir. 2014. Dasar-Dasar Perbankan. Jakarta: PT. Raja Grafindo Persada.

Katuuk, Putri Mawar. Kumaat, Robby J dan. Niode, Audie O. 2018. Pengaruh DPK, LDR, dan BOPO terhadap ROA Bank Umum di Indonesia. Jurnal Berkala Ilmiah Efisiensi Volume 18 No. 02.

Kuncoro, Mudrajad dan Suhardjono. 2002. Manajemen Perbankan. Yogyakarta: BPFE.

Lemiyana dan Litriani, Erdah. 2016. Pengaruh NPF, FDR, BOPO terhadap ROA pada Bank Umum Syariah. I-Economic Vol. 2, No. 1.

Lestari, Wangi. 2013. Rasio Kesehatan Bank Terhadap Kinerja Keuangan Bank Syariah. Skripsi Universitas Muhammadiyah, Purwokerto.

Mawardi, Wisnu. 2005. "Analisis Faktor-Faktor yang Mempengaruhi Kinerja Keuangan Bank Umumdi Indonesia (Studi Kasus pada Bank Umum dengan Total Asset Kurang dati 1 Triliun)". Jurnal Bisnis Strategi,Vol.14, No.1.

Muhammad. 2005. Manajemen Bank Syariah. Yogyakarta: UPP AMP YKPN.

Munawir. 2014. Analisa Laporan Keuangan. Yogyakarta: Leberty.

Muslich, Mohamad. 2013. Manajemen Keuangan Modern. Jakarta, Bumi Aksara.

Najmudin. 2011. Manajemen Keuangan dan Aktualisasi Syariah Modern. Yogyakarta: Andi.

Nasution, Zubaidah dan Khalifaturofi'ah, Sholikha Oktavi. 2016. Analisis Faktor Yang Mempengaruhi Kinerja Keuangan Perbankan Di Indonesia. Jurnal Perbankan Syariah, Vol. 1, No. 01.

Pandia, Frianto. 2012. Manajemen Dana dan Kesehatan Bank. Jakarta: Rineka Cipta.

Parenrengi, Sudarmin dan Whisnu, Tyahya. 2018. Pengaruh DPK, Kecukupan Modal dan Penyaluran Kredit terhadap Profitabilitas Bank. Jurnal Manajemen Strategi dan Aplikasi Bisnis, Vol 1, N0, 1.

Prasetiyo, Luhur. 2012. Analisis Rentabilitas Bank Umum Syariah di Indonesia. Jurnal Bank Syariah, Volume 6, No.1.

Rifai, Fahrur dan Suyono, Nanang Agus. 2019. Pengaruh CAR, NPF, FDR dan NOM terhadap Profitabilitas Bank Syariah yang terdaftar di Otoritas Jasa Keuangan (OJK). Journal of Economic, Business and Engineering Vol. 1, No. 1. 
Riyadi, Slamet. 2004. Banking Asset \& Liabillity Management. Jakarta: Lembaga Penerbit Fakultas Ekonomi, Universitas Indonesia.

Santoso, Rudy Tri. 2000. Prinsip Dasar Akuntansi Perbankan. Yogyakarta: Andi Offset.

Setyawati, Irma. 2018. Bank Umum Syariah di Indonesia : Peningkatan Laba dan Pertumbuhan Melalui Pengembangan Pangsa Pasar. Yogyakarta: Expert.

Simongkir. 2004. Pengantar Lembaga Keuangan Bank dan Nonbank. Jakarta: Ghalia Indonesia.

Susanti, Ana Laili. 2016. Pengaruh Pendapatan Operasional, Pendapatan Non Operqsional, Biaya Operasional, dan Biaya Non Operasional Terhadap Laba Pada PT. Bank BCA Syariah. Skripsi IAIN Tulungagung.

Taswan. 2009. Manajemen Lembaga Keuangan Mikro. Semarang: Badan Penerbit Fakultas Ekonomi Universitas Stikubank.

Umam, Khaerul. 2013. Manajemen Perbankan Syariah. Bandung: Pustaka Setia.

Umar, Husein. 2013. Metodologi Penelitian Untuk Skripsi dan Tesis Bisnis. Jakarta: Rajawali Perss.

Usanti, Trisadini P. dan Shomad, Abd. 2013. Transaksi Bank Syariah. Jakarta: Bumi Aksara.

Veithzal Rivai dan Arviyan Arifin, Islamic Banking: Sebuah Teori, Konsep dan Aplikasi, (Jakarta: PT. BumiAksara, 2010), hal.84.

Wibowo, Edhi Satriyo dan Syaichu, Muhammad. 2013. Analisis Pengaruh Suku Bunga, Inflasi, CAR, BOPO, NPF terhadap Profitabilitas Bank Syariah. Diponegoro Journal of Accounting Volume 2, Nomor 2.

Widyawati, Giofani Nursucia dan Djazari, M. 2017. Pengaruh CAR, NPF, OER, PPAP dan NOM terhadap Profitabilitas pada Bank Umum Syariah. Jurnal Profita Edisi 2.

Yudiana, Fitria Eka. Manajemen Pembiayaan Bank Syariah. Salatiga: STAIN Salatiga Press. Yusuf, Muhammad. 2017. Dampak Indikator Keuangan terhadap Profitabilitas Bank Umum Syariah di Indonesia. Jurnal Keuangan dan Perbankan, Vol 13 No. 2. 